\title{
Meganema perideroedes gen. nov., sp. nov., a filamentous alphaproteobacterium from activated sludge
}

Correspondence

Per H. Nielsen

phn@bio.aau.dk

\author{
Trine R. Thomsen, ${ }^{1}$ Linda L. Blackall, ${ }^{2}$ Marilena Aquino de Muro, ${ }^{1}$ \\ Jeppe L. Nielsen ${ }^{1}$ and Per H. Nielsen ${ }^{1}$ \\ ${ }^{1}$ Section of Environmental Engineering, Aalborg University, Sohngaardsholmsvej 57, DK-9000
Aalborg, Denmark \\ ${ }^{2}$ Advanced Wastewater Management Centre, School of Molecular and Microbial Sciences, \\ The University of Queensland, St Lucia, Queensland 4072, Australia
}

An industrial wastewater treatment plant at Grindsted, Denmark, has suffered from bulking problems for several years caused by filamentous bacteria. Five strains were isolated from the sludge by micromanipulation. Phylogenetic analysis of the $16 \mathrm{~S}$ rRNA gene sequences showed that the strains formed a monophyletic cluster in the Alphaproteobacteria, and they were phenotypically different from their closest relatives and from all hitherto known filamentous bacteria described (closest relative Brevundimonas vesicularis ATCC $11426^{\top}, 89 \cdot 8 \%$ sequence similarity). In pure culture, the cells $(1.5-2.0 \mu \mathrm{m})$ in filaments are Gram-negative and contain polyphosphate and polyhydroxyalkanoates. The optimum temperature for growth is $30^{\circ} \mathrm{C}$ and the strains grow in $2 \%$ $\mathrm{NaCl}$ and are oxidase- and catalase-positive. Ubiquinone 10 is the major quinone. The major fatty acid $\left(\mathrm{C}_{18: 1} \omega 7 \mathrm{c}\right)$ and smaller amounts of unsaturated fatty acids, 3-hydroxy fatty acids with a chain length of 16 and 18 carbon atoms and small amounts of 10-methyl-branched fatty acids with 18 carbon atoms $\left(\mathrm{C}_{19: 0}\right.$ 10-methyl) affiliated the strains with the Methylobacterium/Xanthobacter group in the Alphaproteobacteria. The $\mathrm{G}+\mathrm{C}$ content of the DNA is $42.9 \mathrm{~mol} \%$ (for strain $\mathrm{Gr} 1^{\top}$ ). The two most dissimilar isolates by $16 \mathrm{~S}$ rRNA gene comparison $\left(\mathrm{Gr}^{\top}{ }^{\top}\right.$ and $\mathrm{Gr} 10 ; 97 \cdot 7 \%$ identical) showed $71.5 \%$ DNA-DNA relatedness. Oligonucleotide probes specific for the pure cultures were designed for fluorescence in situ hybridization and demonstrated that two filamentous morphotypes were present in the Grindsted wastewater treatment plant. It is proposed that the isolates represent a new genus and species, Meganema perideroedes gen. nov., sp. nov. The type strain of Meganema perideroedes is strain $\operatorname{Gr}^{\top}\left(=\mathrm{DSM} 15528^{\top}=\mathrm{ATCC}^{\mathrm{BAA}}-740^{\top}\right)$.
Filamentous bacteria affiliated to the Alphaproteobacteria were isolated from activated sludge biomass from a wastewater treatment plant (WWTP) in Grindsted, Denmark. The treatment plant has carbon removal, the mean cell residence time (sludge age) is $8-10$ days, the annual mean temperature is $15-25^{\circ} \mathrm{C}$ and the salinity is relatively high, with a conductivity between 15 and $23 \mathrm{mS} \mathrm{cm}^{-1}$ and a sodium concentration around 5-7 $\mathrm{g} \mathrm{l}^{-1}$. The plant has been

\footnotetext{
Abbreviations: FISH, fluorescence in situ hybridization; $\mathrm{PHB}$, poly- $\beta$ hydroxybutyrate; WWTP, wastewater treatment plant.

The GenBank/EMBL/DDBJ accession numbers for the 16S rRNA gene sequences of strains $\mathrm{Gr} 1^{\top}, \mathrm{Gr} 2, \mathrm{Gr} 5, \mathrm{Gr} 10$ and $\mathrm{Gr} 28$ are AF180468 and AY170117-AY170120.

Interstrain 16S rRNA gene sequence similarities, confocal laser scanning micrographs of FISH of activated sludge from Grindsted WWTP and a phase-contrast micrograph of filaments of strain $\mathrm{Gr}^{\top}{ }^{\top}$ are available as supplementary material in IJSEM Online.
}

affected by bulking problems for several years, mainly caused by Thiothrix spp. (Nielsen et al., 2000) and other bacteria similar to the isolates reported in this study. Five strains $\left(\mathrm{Gr}^{\mathrm{T}}{ }^{\mathrm{T}}, \mathrm{Gr} 2, \mathrm{Gr} 5, \mathrm{Gr} 10\right.$ and Gr28) were isolated by micromanipulation using a Skerman micromanipulator as described by Blackall (1991) and grown on R2A agar medium (Reasoner \& Geldreich, 1985). Gliding motility, Gram- and Neisser-staining (for Gram-reaction and polyphosphate inclusions, respectively; Eikelboom \& van Buijsen, 1983) and poly- $\beta$-hydroxybutyrate (PHB) inclusions as visualized by Nile blue staining (Ostle \& Holt, 1982) were investigated. Only $\mathrm{Gr}^{\mathrm{T}}$ and $\mathrm{Gr} 10$ were characterized phenotypically, but they were not able to grow on minimal media (Williams \& Unz, 1985), so a full characterization of the growth requirements was not possible. Biolog analysis was done according to the manufacturer's description (http://www.biolog.com/main.html). However, reproducible results could not be obtained, so the results are therefore 
not described here. The temperature range and salt tolerance for growth were also studied. The results obtained are given in the species description below.

Phylogenetic analysis was performed on the 16S rRNA gene as described by Blackall (1994). Nearly complete $16 \mathrm{~S}$ rRNA gene sequences $\left(\mathrm{Gr}^{\mathrm{T}}{ }^{\mathrm{T}}, 1383 \mathrm{bp}\right.$; Gr2, $1284 \mathrm{bp} ; \mathrm{Gr} 5,1208 \mathrm{bp}$; Gr10, 1234 bp; Gr28, 1214 bp) were compiled and aligned using the automatic nucleic acid aligner in the ARB software package (http://www.arb-home.de) and alignments were refined manually. A total of 1208 unambiguously aligned nucleotides from position 70 to 1277 were used for calculation of trees by distance matrix, parsimony and maximumlikelihood approaches using default settings in the ARB software. The methods used generated congruent tree topologies and a maximum-likelihood tree is shown in Fig. 1. The five isolates always formed a monophyletic cluster within the Alphaproteobacteria, and the 16S rRNA gene sequence similarity in this cluster ranged between $97 \cdot 7$ and 99.6 \% (for individual values see Supplementary Table S1 in IJSEM Online). Strains $\mathrm{Gr}^{\mathrm{T}}$ and Gr10 and $\mathrm{Gr} 1^{\mathrm{T}}$ and $\mathrm{Gr} 2$ were the most dissimilar strains by $16 \mathrm{~S}$ rRNA gene comparison, showing $97 \cdot 7 \%$ identity. The closest relative was Brevundimonas vesicularis LMG $2350^{\mathrm{T}}$, which showed $89 \cdot 8 \%$ identity with strain $\mathrm{Gr}^{\mathrm{T}}$. Levantesi et al. (2004) reported on other filamentous alphaproteobacteria. They are so far described only by $16 \mathrm{~S}$ rRNA gene sequences from uncultured bacteria or from isolates that have not yet been described. These are all closely related to the novel strains.

The detailed results of chemotaxonomic analysis are given in the species description. The following analytical procedures were performed. Respiratory quinones and cellular fatty acids were analysed at the DSMZ according to Tindall (1990a, b) and Sasser (1990). Ubiquinone 10 (Q-10) was the major quinone component in strain $\mathrm{Gr}^{\mathrm{T}}$ and Gr10, supporting the affiliation of $\mathrm{Gr}^{\mathrm{T}}$ to the Alphaproteobacteria, where the majority of the species have Q-10 as the major quinone (Lechner et al., 1995; Yokota et al., 1992). Both strains synthesized mainly straight-chain saturated and unsaturated fatty acids and 3-hydroxy fatty acids with a chain length of 16 and 18 carbon atoms. Small amounts of 10-methyl-branched fatty acids with 18 carbon atoms $\left(\mathrm{C}_{19: 0}\right.$ 10-methyl) were also found. According to the fatty acid patterns, the two strains were assigned to the Methylobacterium/Xanthobacter group within the Alphaproteobacteria.
The $\mathrm{G}+\mathrm{C}$ content was determined at the DSMZ according to a standard protocol (Mesbah et al., 1989; Tamaoka \& Komagata, 1984). The G $+\mathrm{C}$ content of DNA of strain $\mathrm{Grl}^{\mathrm{T}}$ was $42 \cdot 9 \mathrm{~mol} \%$. DNA-DNA hybridization was carried out at the DSMZ as described by De Ley et al. (1970), with the modifications described by Huß et al. (1983) and Escara \& Hutton (1980). Strain Gr1 ${ }^{\mathrm{T}}$ and Gr10 had high DNA-DNA relatedness $(71.5 \%)$, supporting the conclusion that the two strains can be regarded as members of one species.

Oligonucleotide probes specific for the isolated filaments were designed using the probe design/match tools of the ARB software package (http://www.arb-home.de; Hugenholtz et al., 2002). Fluorescence in situ hybridization (FISH) was carried out as described by Amann (1995) and visualized with a Zeiss LSM 510 (Carl Zeiss) confocal laser scanning microscope. Oligonucleotide probes were $5^{\prime}$-labelled with 5(6)-carboxyfluorescein- $N$-hydroxy-succinimide ester (FLUOS) or with sulfoindocyanine dyes ( $\mathrm{Cy} 3$ and Cy5) (Thermo Hybaid). Probe-binding profiles of the designed probes (Meg983 and Meg1028) for FISH were determined using image analysis and with hybridization buffers containing 0 to $60 \%$ formamide at $5-10 \%$ increments (Amann, 1995), initially employing the isolates (perfect probe matches) as probe target organisms and Streptococcus salivarius ATCC $7073^{\mathrm{T}}$ (one central mismatch with probe Meg983) and Escherichia coli ATCC 25922 (more than seven mismatches with Meg983 and Meg1028) as non-target organisms. Two probes were designed for the strains isolated in this study: S-Ss-Meg-983-a-A-19 (Meg983), 5' CGGGATGTCAAAAGGTGG-3', and S-Ss-Meg-1028-a-A19 (Meg1028), 5'-CTGTCACCGAGTCCCTTGC-3'. Both probes targeted the novel strains perfectly, as well as the strains described by Levantesi et al. (2004). Probe binding profiles of hybridized pure cultures $\left(\mathrm{Gr}^{\mathrm{T}}, \mathrm{Gr} 2\right.$ and $\left.\mathrm{Gr} 10\right)$ and Grindsted sludge samples showed probe Meg983 hybridized well up to $35 \%$ formamide, while the intensity of probe Meg1028 decreased above 50\% formamide. Only one clone, clone oc48 (GenBank accession no. AY491589), was found using ARB and RDP (http://rdp.cme.msu.edu/ html) with a weighed mismatch below 1.5 to probe Meg1028, indicating that the probe is very specific. Probe Meg983 was less specific so, for in situ identification, it is recommended to use the two probes in combination with two different fluorochromes at $35 \%$ formamide or to use

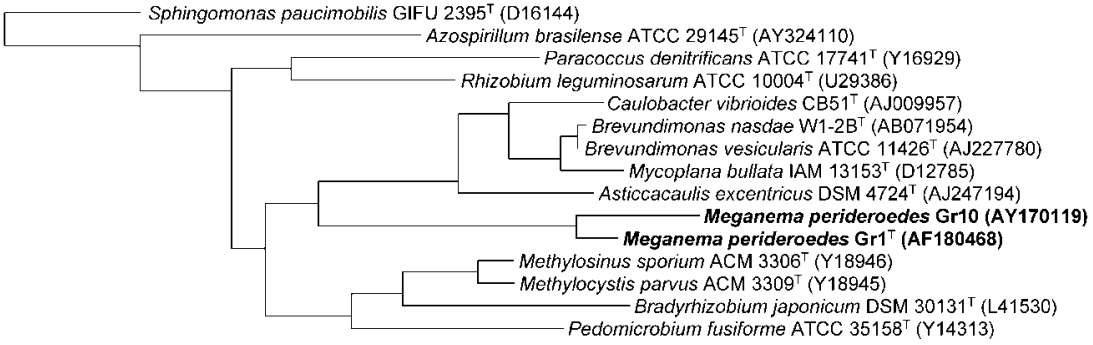

$10 \%$
Fig. 1. Maximum-likelihood tree based on 16S rRNA gene sequences of strains $\mathrm{Gr}{ }^{\top}$ and $\mathrm{Gr} 10$ and related organisms calculated using default settings in the ARB software. Bar, $10 \%$ estimated sequence divergence. 
probe Meg1028 only (at $45 \%$ formamide). E. coli ATCC 25922 was used as a non-target organism for both probes, and positive hybridization signals were never observed. Micrographs from FISH of activated sludge from Grindsted WWTP are available as Supplementary Fig. S1 in IJSEM Online. The application of the specific 16S rRNA-targeted oligonucleotide probes allowed the monitoring of sludge samples from Grindsted WWTP for the novel organism (Meganema perideroedes). In all samples from the past 3 years, Meganema perideroedes filaments predominated in the sludge. Thiothrix and other filamentous bacteria were present in moderate numbers. Morphological observations, staining reactions and FISH of the Grindsted sludge sample showed the presence of two variations of Meganema perideroedes. Filaments of type A were about $1.5 \mu \mathrm{m}$ wide, some filaments were Gram-positive, others were Gram-negative and filaments containing both Gram-positive and Gramnegative cells were also found. Some of the filaments were Neisser-negative (no purple granules inside red cells), while others contained Neisser-positive granules (purple inclusions) and thus contained polyphosphate. The cells contained large PHB granules according to Nile blue staining. Type B filaments were slightly wider than those of type A and they showed Gram-variable staining similar to type A. PHB granules were smaller in type B filaments than in type A filaments. The isolated strains were very similar to type A filaments from Grindsted. Thus, the isolated strains look like the Gram-variable filamentous bacteria in activated sludge with the 'Nostocoida limicola' type II morphology described by Eikelboom \& van Buijsen (1983). This morphotype was also observed in previous studies (Snaidr et al., 2002; Schade et al., 2002; Blackall et al., 2000; Levantesi et al., 2004). Our results confirm the observation that different filaments from the ' $N$. limicola' type II morphotype are phylogenetically heterogeneous, emphasizing that accurate identification in situ is impossible without the application of gene probes. Nevertheless, the specific gene probes designed for the Meganema perideroedes sequences were not able to differentiate between the type A and type B morphotypes observed in sludge from Grindsted WWTP.

\section{Description of Meganema gen. nov.}

Meganema (Me.ga.ne'ma. Gr. nom. neut. adj. mega big; Gr. nom. neut. n. nema thread; N.L. neut. n. Meganema large thread-like micro-organism).

Filamentous bacteria. Cells stain Gram-negative and contain some Neisser-positive granules and PHB granules. The major quinone is Q-10. Fatty acid profiles are dominated by $\mathrm{C}_{18: 1} \omega 7 c$; characteristic hydroxy acids are $\mathrm{C}_{14: 0} 3-\mathrm{OH}$ and $\mathrm{C}_{18: 0} 3-\mathrm{OH}$. Meganema belongs to the Alphaproteobacteria and the type species is Meganema perideroedes.

\section{Description of Meganema perideroedes sp. nov.}

Meganema perideroedes (pe.ri.de.ro'ed.es. Gr. nom. neut. adj. perideroedes necklace-like).
The species shares the characteristics listed in the genus description. The DNA G+C content of the type strain is $42.9 \mathrm{~mol} \%$. Habitat: mixed liquors of activated sludge WWTP. Although all isolates grow on R2A medium, some $\left(\mathrm{Gr} 1^{\mathrm{T}}, \mathrm{Gr} 2\right.$ and Gr10) grow well, taking only a few days to produce macroscopically visible colonies, which are dense and white. Storage of strains Gr5 and Gr28 was unsuccessful and the strains were lost after sequencing of their 16S rRNA genes. Strains $\mathrm{Gr} 1^{\mathrm{T}}, \mathrm{Gr} 2$ and $\mathrm{Gr} 10$ demonstrate a very similar morphology in that the cells in all filaments are irregularly disc-shaped and are approximately $1 \cdot 5-2 \mu \mathrm{m}$ in diameter (see Supplementary Fig. S2); they show no gliding motility. Gram- and Neisser-staining shows that they are Gram-negative and contain Neisser-positive granules. Only strains $\mathrm{Gr} 1^{\mathrm{T}}$ and Gr10 have been characterized phenotypically; they are not able to grow on minimal media, so a full characterization of the growth requirements has not been possible. They are not able to grow anaerobically with nitrate as an electron acceptor. Starch and tributyrin are not hydrolysed. Oxidase and catalase activities are present. The temperature range for growth is $15-35^{\circ} \mathrm{C}$ and the optimum temperature for growth is $25-30^{\circ} \mathrm{C}$. Both strains are able to grow in the presence of $\mathrm{NaCl}$ concentrations up to $2 \%$, but do not grow in the presence of $3 \% \mathrm{NaCl}$. The fatty acid profile of the type strain $\mathrm{Grl}^{\mathrm{T}}$ is composed of $\mathrm{C}_{18: 1} \omega 7 \mathrm{c}$ $(86 \cdot 4 \%), \mathrm{C}_{18: 0}(3 \cdot 8 \%)$, summed feature $2\left(\mathrm{C}_{14: 0} 3-\mathrm{OH}\right)$ $(2 \cdot 4 \%), \mathrm{C}_{16: 0}(2 \cdot 9 \%), \mathrm{C}_{18: 0} 3-\mathrm{OH}(2 \cdot 3 \%)$ and $\mathrm{C}_{19: 0} 10-$ methyl $(1 \cdot 1 \%)$. The profile of strain Gr10 is almost identical.

The type strain is strain $\mathrm{Grl}^{\mathrm{T}}\left(=\mathrm{DSM} 15528^{\mathrm{T}}=\right.$ ATCC BAA- $-740^{\mathrm{T}}$ ), isolated by micromanipulation from sludge of an industrial WWTP at Grindsted, Denmark. There are currently three extant strains in the species.

\section{Acknowledgements}

The study is a part of the framework programme 'Activity and Diversity of Complex Microbial Systems' funded by the Danish Technical Research Council. We thank Jane Ildal and Marianne Stevenson for their valuable technical assistance. Professor Mogens Kilian, Department of Medical Microbiology, University of Aarhus, Denmark, is acknowledged for providing Streptococcus salivarius ATCC $7073^{\mathrm{T}}$. Professor Bob Milns, Department of Classic \& Ancient History, University of Queensland, Australia, is acknowledged for naming Meganema perideroedes and Dr Hans-Jürgen Busse, Institut für Bakteriologie, Mykologie und Hygiene, Veterinärmedizinische Universität Wien, Austria, is thanked for advice regarding the taxonomic investigations.

\section{References}

Amann, R. I. (1995). In situ identification of microorganisms by whole cell hybridization with rRNA-targeted nucleic acid probes. In Molecular Microbial Ecology Manual, pp. MMEM-3.3.6/1 - MMEM3.3.6/15. Edited by A. D. L. Akkermans, J. D. van Elsas \& F. J. de Bruijn. London: Kluwer Academic.

Blackall, L. L. (1991). Use of the Skerman micromanipulator for isolating actinomycetes in the wastewater field. Actinomycetes 2, $8-12$. 
Blackall, L. L. (1994). Molecular identification of activated sludge foaming bacteria. Water Sci Technol 29, 35-42.

Blackall, L. L., Seviour, E. M., Bradford, D., Rossetti, S., Tandoi, V. \& Seviour, R. J. (2000). 'Candidatus Nostocoida limicola', a filamentous bacterium from activated sludge. Int J Syst Evol Microbiol 50, 703-709.

De Ley, J., Cattoir, H. \& Reynaerts, A. (1970). The quantitative measurement of DNA hybridization from renaturation rates. Eur $J$ Biochem 12, 133-142.

Eikelboom, D. H. \& van Buijsen, H. J. J. (1983). Microscopic Sludge Investigation Manual, 2nd edn, pp. 1-100. Delft: TNO Research Institute for Environmental Hygiene.

Escara, J. F. \& Hutton, J. R. (1980). Thermal stability and renaturation of DNA in dimethyl sulfoxide solutions: acceleration of the renaturation rate. Biopolymers 19, 1315-1327.

Hugenholtz, P., Tyson, G. W. \& Blackall, L. L. (2002). Design and evaluation of 16S rRNA-targeted oligonucleotide probes for fluorescence in situ hybridization. In Gene Probes: Principles and Protocols, pp. 29-42. Edited by M. Aquino de Muro \& R. Rapley. Totowa, NJ: Humana Press.

Huß, V. A. R., Festl, H. \& Schleifer, K. H. (1983). Studies on the spectrophotometric determination of DNA hybridization from renaturation rates. Syst Appl Microbiol 4, 184-192.

Lechner, U., Baumbach, R., Becker, D., Kitunen, V., Auling, G. \& Salkinoja-Salonen, M. (1995). Degradation of 4-chloro-2-methylphenol by an activated sludge isolate and its taxonomic description. Biodegradation 6, 83-92.

Levantesi, C., Beimfohr, C., Geurkink, B., Rossetti, S., Thelen, K., Krooneman, J., Snaidr, J., van der Waarde, J. \& Tandoi, V. (2004). Filamentous alphaproteobacteria associated with bulking in industrial wastewater treatment plants. Syst Appl Microbiol 27, 716-727.

Mesbah, M., Premachandran, U. \& Whitman, W. B. (1989). Precise measurements of the $\mathrm{G}+\mathrm{C}$ content of deoxyribonucleic acid by high-performance liquid chromatography. Int J Syst Bacteriol 39, 159-167.
Nielsen, P. H., Aquino de Muro, M. \& Nielsen, J. L. (2000). Studies on the in situ physiology of Thiothrix spp. present in activated sludge. Environ Microbiol 2, 389-398.

Ostle, A. G. \& Holt, J. G. (1982). Nile blue A as a fluorescent stain for poly- $\beta$-hydroxybutyrate. Appl Environ Microbiol 44, 238-241.

Reasoner, D. J. \& Geldreich, E. E. (1985). A new medium for the enumeration and subculture of bacteria from potable water. Appl Environ Microbiol 49, 1-7.

Sasser, M. (1990). Identification of bacteria by gas chromatography of cellular fatty acids. MIDI Technical Note 101. Newark, DE: MIDI Inc.

Schade, M., Beimfohr, C. \& Lemmer, H. (2002). Phylogenetic and physiological characterization of a Nostocoida limicola-like organism isolated from activated sludge. Water Sci Technol 46 (1-2), 91-97.

Snaidr, J., Beimfohr, C., Levantesi, C., Rossetti, S., van der Waarde, J., Geurkink, B., Eikelboom, D., Lemaitre, M. \& Tandoi, V. (2002). Phylogenetic analysis and in situ identification of "Nostocoida limicola"-like filamentous bacteria in activated sludge from industrial wastewater treatment plants. Water Sci Technol 46 (1-2), 99-104.

Tamaoka, J. \& Komagata, K. (1984). Determination of DNA base composition by reversed-phase high-performance liquid chromatography. FEMS Microbiol Lett 25, 125-128.

Tindall, B. J. (1990a). A comparative study of the lipid composition of Halobacterium saccharovorum from various sources. Syst Appl Microbiol 13, 128-130.

Tindall, B. J. (1990b). Lipid composition of Halobacterium lacusprofundi. FEMS Microbiol Lett 66, 199-202.

Williams, T. M. \& Unz, R. F. (1985). Filamentous sulfur bacteria of activated sludge: characterization of Thiothrix, Beggiatoa, and Eikelboom type 021N strains. Appl Environ Microbiol 49, 887-898.

Yokota, A., Akagawe-Matsushita, M., Hiraishi, A., Katayama, Y., Urakami, T. \& Yamasato, K. (1992). Distribution of quinone systems in microorganisms: gram-negative eubacteria. Bull Jpn Fed Cult Coll 8, 136-171. 